\title{
Formulation and evaluation of CFC free inhalers for beclomethasone dipropionate
}

\author{
Gopala Krishna Murthy Talasila',"*, Bala Vishnu Priya Mukkala ${ }^{1}$, Satyanarayana Vattikuri² \\ ${ }^{1}$ Department of Pharmaceutics, Bapatla College of Pharmacy, Bapatla, India, ${ }^{2}$ Natco Pharma Limited, Kothur, India
}

\begin{abstract}
Beclomethasone dipropionate $\mathrm{CFC}$ free inhalation formulations were developed with a view to treat asthma prophylactically. Dry powder inhalers (DPI) for beclomethasone dipropionate were prepared with different grades of lactose monohydrate. The influence of carrier and overages on performance of DPI was studied. Metered dose inhalers (MDI) with HFA based propellants were formulated with various doses, overages and different concentrations of alcohol. Formulated DPI and MDI were evaluated for various official and unofficial quality control tests. The influence of over doses on valve delivery, effect of overages on emitted dose and influence of alcohol on spray pattern from MDI were studied. The better fine particle fraction and emitted dose were obtained from the DPI formulated with 10:90 ratio of fine lactose: coarse lactose and with $20 \% \mathrm{w} / \mathrm{w}$ overages. The studies on MDI revealed that the $15 \%$ of overdoses are required for effective valve delivery and $20 \%$ overages are required for $100 \%$ drug delivery. $5-10 \% \mathrm{v} / \mathrm{v}$ alcohol was found to be preferable to get optimum emitted dose and fine particle fraction.
\end{abstract}

Uniterms: Beclomethasone dipropionate. Dry powder inhalers. Metered dose inhalers,, emmited dose. Fine particle fraction, overages

\begin{abstract}
Desenvolveram-se formulações por inalação de dipropionato de beclometasona, livres de CFC, com o objetivo de tratar a asma profilaticamente. Prepararam-se inaladores de pó seco (DPI) para o dipropionato de beclometasona com diferentes gradações de lactose monoidratada. Estudou-se a influência do transportador e dos excessos de fármaco em relação ao rotulado no desempenho do DPI. Inaladores de dose calibrada (MDI) com propelentes à base de hidrofluoralcanos (HFA) foram formulados com várias doses, excessos de fármaco em relação ao rotulado e diferentes concentrações de álcool. Avaliaram-se as DPI e MDI formuladas por vários métodos oficiais e não oficiais de controle de qualidade. Estudaram-se a influência da superdosagem na liberação da válvula, o efeito dos excessos na dose emitida e a influência do álcool no padrão do spray do MDI. Obtiveram-se a melhor partícula fina e a dose emitida do DPI formulado com proporção de 10:90 de lactose fina:lactose grossa e 20\% p/p de excesso. Os estudos em MDI revelaram que $15 \%$ de sobredose são requeridos para a liberação efetiva da válvula e $20 \%$ de excessos, para a liberação de $100 \%$ dos fármacos. Álcool a $5-10 \% \mathrm{v} / \mathrm{v}$ permitiu alcançar ótima dose emitida e fração de partícula fina.
\end{abstract}

Unitermos: Dipropionato de beclometasona. Inaladores pó seco. Inalantes de dose cvalibrada, dose emitida. Fração de partículas finas, excessos.

\section{INTRODUCTION}

Nowadays, drugs are delivered via many portals into the body using a variety of dosage forms which allow medicines administration. Relatively recent pharmaceutical development is the delivery of drug via the lung. The onset of action from this route is relatively fast compared

*Correspondence: T.E.G.K. Murthy. Bapatla College of Pharmacy, Bapatla522 101, India. E-mail: gopalakrishnatalasila@yahoo.com with the oral \& external routes of administration. Metered dose inhalers were most widely used in the treatment of respiratory airway diseases (Bisgard et al., 2002; Williams et al., 2008). Metered dose inhaler was first introduced in 1950s by Ricker laboratories with chlorofluorocarbons propellants. All MDIs marketed prior to 1995 contained chlorofluorocarbons (CFC) as a propellant. CFC propellants damage the ozone layer present in stratosphere, which protects the earth from ultraviolet radiation by filtering the ultraviolet-B radiation from the sun. Their production has 
been banned since 1996 under the terms of the Montreal protocol (1994) and alternative formulation (Dry powder formulations and hydrofluroalkane (HFA) propellant based MDI formulations) development was started to replace the $\mathrm{CFC}$ formulations and to protect the ozone layer. Some reformulated metered dose inhalers are designed to improve the proportion of drug delivered into the lungs and to reduce the dose. Dry powder inhalers (DPIs) are devices through which a dry powder form of an active drug is delivered for local or systemic effect via the pulmonary route.

Beclomethasone dipropionate is indicated for the maintenance and treatment of asthma. A major advance in asthma therapy is the development of inhalers that target the drug directly to the relevant site of inflammation. These formulations greatly enhance the therapeutic index of the drugs, substantially diminishing the incidence of side effects without altering clinical utility (Sweetman, 2009; Merck index)

The performance of dry powder inhaler was depended on the morphology of carrier. The influence of carrier roughness on performance of dry powder inhalers was studied (Saint-Lorant et al., 2007; Flament et al., 2004). The metered dose inhalers of beclomethasone dipropionate were developed with propellant R 134a (Hartwig et al., 1998; Michael et al., 1996).

Beclomethasone dipropionate dry powder inhalers were formulated with different grades of fine and coarse lactose. Beclomethasone MDIs were prepared by incorporating overdoses, overages and different proportions of alcohol. The effect of formulation variables on efficiency of DPIs and MDIs studied and results are reported herein.

\section{MATERIAL AND METHODS}

Beclomethasone dipropionate, various grades of lactose monohydrate (alctoste), HFA 134a (Zephex 134a), alcohol, Bespack metered valves, Bespack actuators were collected from NATCO, Hyderabad.

Dosage unit sampling apparatus (Erweka), Anderson cascade impactor (Mark-II, Erweka), Twin stage impinger (Erweka), High performance liquid chromatography (Empower, Waters), Vacuum pump (Erweka), Flow meter (Erweka), Pamasol filling crimping machine (P2005, Pamsol ), and Capsules partial filling machine (AF25(T), Pham) were used in this investigation.

\section{Formulation of DPI}

An accurately weighed amount of beclomethasone dipropionate (particle size $>5 \mu$ ) was blended in poly bag for 5 minutes separately in each case with different quanti- ties/various grades of lactose of monohydrate in geometric progress. The blend was passed through $60 \#$ mesh and filled in to size " 3 " hard gelatin capsules with partial filling manual capsule filling machine. The total fill weight of capsule is $25 \mathrm{mg}$ per capsule.

Beclomethasone dipropionate $(200 \mu \mathrm{g})$ formulations were prepared with $0-20 \%$ of overages. DPI was also prepared with different proportions of fine lactose $(0,5,10$, 15,20 and 30\%) and coarse lactose. Further the inhalers containing two different grades of fine lactose $(10 \%)$ and $90 \%$ of coarse lactose and inhalers containing various grades of coarse lactose along with $10 \%$ fine lactose were also prepared.

\section{Formulation of HFA based MDI}

An accurately weighed $40 \mathrm{mg}$ (equivalent to 200 doses to deliver $200 \mu \mathrm{g} /$ dose) of beclomethasone dipropionte was dissolved in $1.6 \mathrm{~g}$ of alcohol, transferred in to aluminum cans crimped with metered valve by Pamasol 2005 and filled with the $16.4 \mathrm{~g}$ of HFA 134a by Pamasol 2005 propellant filling machine (pressure filling method).

Beclomethasone dipropionate HFA MDI $200 \mu \mathrm{g}$ formulations were prepared with overdoses $(0-15 \%)$ to study the effect of extra doses on valve delivery. The effect of overages on emitted dose was also studied from these formulations by incorporating the $(0-20 \% \mathrm{w} / \mathrm{w})$ overages to the MDI formulation containing $15 \%$ overdose. To study the effect of alcohol on spray pattern, leak rate, alcohol ranging from $0-20 \% \mathrm{w} / \mathrm{w}$ was incorporated in the metered dose inhaler formulations.

\section{Evaluation}

\section{Drug compatibility studies}

The compatibility of beclomethasone with lactose, alcohol and HFA was investigated with HPLC technique developed and validated in our Institution. Accurately $20 \mathrm{mg}$ of beclomethasone was weighed and transferred into $100 \mathrm{~mL}$ volumetric flask. The drug was dissolved in $60 \mathrm{~mL}$ of methanol:water (70:30) mixture (mobile phase). It was sonicated and diluted with the mobile phase up to the mark. The resulting solution was suitably diluted and injected into the Nova-pak C18(3.9 mm x $150 \mathrm{~mm}, 4 \mu)$ column maintained at $30^{\circ} \mathrm{C}$. The flow rate of mobile phase was maintained at $1.5 \mathrm{~mL} / \mathrm{min}$ for 9 min runtime. The sample was detected at $239 \mathrm{~nm}$.

\section{Evaluation of dry powder inhaler formulations}

The formulated DPI were evaluated for following parameters. 


\section{Physical appearance}

The capsules were visually inspected to identify the defects.

\section{Average fill weight per capsule}

Twenty capsules are collected randomly and their collective weight were recorded as $\mathrm{W}_{1}$. The contents of 20 capsules were removed and the weight of the empty capsule shells was determined as $\mathrm{W}_{2}$. The difference between those two weights was the fill weight of 20 capsules. The average fill weight per capsule was determined with the following formulae Average fill weight $(\mathrm{mg})=\frac{20 \text { Capsules content in } \mathrm{mg}}{20}$

\section{Assay (drug content determination)}

Drug content was determined by HPLC technique. The samples containing equivalent to $200 \mu \mathrm{g}$ of beclomethasone collected from 20 capsules were analyzed for drug content (Indian Pharmacopoeia, 2007).

\section{Content uniformity}

This test was performed on 10 capsules. Each capsule was transferred separately into a volumetric flask and the shell and the contents of the capsule were treated with $5 \mathrm{~mL}$ of water followed by a solvent mixture of $25 \mathrm{~mL}$ of methanol: water (70:30) mixture (diluent), sonicated for 10 minutes with intermittent shaking (for complete dispersion) and the volume was made up to $50 \mathrm{~mL}$ with diluent. It was then filtered through a $0.45 \mu$ membrane filter and the samples were analyzed by using HPLC technique for drug content. The same procedure was repeated for the remaining 9 capsules.

\section{Uniformity of the delivered dose and emitted dose}

Uniformity of the delivered and emitted dose was determined according to the official procedure specified in Indian Pharmacopoeia (2007). The samples were analyzed with HPLC technique. These tests were performed repeatedly with 10 capsules in each case.

\section{Fine particle dose}

Fine particle dose (FPD) was determined by employing the procedure specified in Indian pharmacopoeia (2007) with the Andersen cascade impactor. The different sample sizes $(10,15 \& 20$ capsules) were employed and the amount of fines retained in different stages was eluted with acetonitrile and the samples were analyzed using HPLC technique. The Mass Median Aerodynamic
Diameter (MMAD) and Geometric Standard Deviation (GSD) were calculated using following formulae:

MMAD $=$ Particle size at $50 \%$ cumulative mass GSD $=(\text { Size X/SizeY })^{1 / 2}=($ MMAD $/$ Size $Y)=($ Size $X /$ MMAD)

Size $\mathrm{X}=$ Particle size at $84.13 \%$ cumulative mass

Size $Y=$ Particle size at $15.87 \%$ cumulative mass

\section{Stability studies}

The optimized beclomethasone dipropionate DPI formulations were stored at $40{ }^{\circ} \mathrm{C} / 75 \% \mathrm{RH}$ and $25^{\circ} \mathrm{C} / 60 \%$ $\mathrm{RH}$ for six months as per IGH guidelines. Later, the formulations were evaluated for assay of number of doses delivered, deposition of emitted dose and net fill weight. The observed data were compared with the initial results.

\section{Evaluation of Metered dose inhaler formulations}

The formulated MDI were evaluated for following parameters:

- Physical appearance

The inhalers were visually observed to identify the defects.

\section{- $\quad$ Drug content determination}

The first 10 , middle 10 and on the last 10 deliveries were collected from the container and the drug content of these deliveries were estimated. The MDI was agitated for $30 \mathrm{~s}$ and kept them in inverted position in the beaker containing diluent (acetonitrile: water (60:40)). Ten deliveries were discharged in the beaker at intervals of 15 seconds. The retained contents from the MDI were collected by washing the MDI device with the diluent and the contents, washings were suitably diluted and analyzed by using HPLC technique.

- Uniformity of the delivered and emitted dose

The uniformity of the delivered and emitted dose were determined according to the official procedure specified in Indian Pharmacopoeia (2007). The sampling device was agitated vigorously for $2 \mathrm{~min}$ and the required number of emitted doses delivered from the valve was collected, transferred in to a $100 \mathrm{~mL}$ volumetric flask. The tube was washed twice using the diluent and then the contents were transferred to a $100 \mathrm{~mL}$ volumetric flask. The final volume was made up to the mark with diluents, sonicated for 5 minutes and filtered through $0.45 \mu$ membrane filter. The same procedure was repeated on nine other containers. The samples were analyzed with HPLC technique.

- $\quad$ Fine particle dose

Fine particle dose (FPD) emitted from the MDI was 
determined by employing Andersen cascade impactor, as specified in Indian pharmacopoeia (2007). The fines retained in different stages were eluted with acetonitrile and the samples were analyzed using HPLC technique.

- $\quad$ Number of doses delivered

The contents of the MDI were discharged by actuating the valve at an interval of not less than 5 seconds and the number of doses discharged from the MDI was observed.

\section{- $\quad$ Leak test}

Randomly 12 aerosol containers were selected, and the date and time was recorded to the nearest half-hour. The container was weighed and the weight was recorded in $\mathrm{mg}$ in each case and denoted as $\mathrm{W}_{1}$. The containers were allowed to stand in upright position at room temperature for a period of three days. Then the weight of the container was observed in $\mathrm{mg}$ in each case denoted as $\mathrm{W}_{2}$. The time interval observed in between $\mathrm{W}_{1}$ and $\mathrm{W}_{2}$ was considered as time interval $\mathrm{T}$. The leakage rate was calculated in $\mathrm{mg}$ per year by using the formulae:

$$
\mathrm{Mg} \text { loss per year }=\frac{365 \times 24 \times(\mathrm{W} 1-\mathrm{W} 2)}{\mathrm{T}}=\ldots \mathrm{mg}
$$

$$
\% \text { Leakage }=\frac{(\mathrm{Mg} / \text { year })(100)}{(\text { Net Fill Weight })}
$$

\section{- $\quad$ Spray pattern}

The contents of the pressurized container were sprayed on a glass slide and the spray pattern was observed for shape and dimensions.

- $\quad$ Valve delivery

The aerosol container with a clean actuator was weighed and the weight was recorded. The actuator was removed and replaced with another actuator and a dose was dispensed. It was again replaced with the original clean actuator and re-weighed. The weight of each individual dose dispensed was recorded. The same procedure was repeated on another nine containers. The average weight of the dose delivered through the valve was calculated and reported as valve delivery (Cummings, 1999; McDonald et al., 2000).

\section{- $\quad$ Stability studies}

Beclomethasone dipropionate HFA MDI $200 \mathrm{mcg}$ packed in aluminum cans were stored at $40{ }^{\circ} \mathrm{C} / 75 \% \mathrm{RH}$ and $25{ }^{\circ} \mathrm{C} / 60 \% \mathrm{RH}$ for a period of six months as per IGH guidelines and evaluated for assay, number of doses delivered, deposition of emitted dose and net fill weight. The samples were collected and analyzed at regular time intervals. The data were compared with the initial results.

\section{RESULTS AND DISCUSSION}

Drug compatibility studies with excipients were conducted by HPLC methods and results indicated the presence of identical chromatograms and were found to be compatible.

Physical properties such as bulk density, tapped density and particle size of various lactose grades were evaluated and showed in Table I. Based on the flow properties lactose grades can be as Lactohale $300<$ Sorbolac $400<$ Respitose SV003 < Flowlac $100<$ Inhalac $230<$ DCL11. Lactohale 300 and Sorbolac 400 alone are not suitable as carriers for dry powder inhalers; hence they were blended with coarse lactose to improve the flow properties.

The influence of overages in dry powder was carried out on beclomethasone dipropionate DPI. All the formulations were formulated with $0-20 \%$ extra quantity of active ingredient. The observed data indicated $8-10 \%$ of drug retention in capsule, 3-6\% of drug deposition in device and $84-88 \%$ of the dose was emitted from the device. To

TABLE I - Physical properties of lactose grades used in DPI formulations

\begin{tabular}{lccccc}
\hline Lactose grade & $\begin{array}{c}\text { Bulk density } \\
(\mathrm{g} / \mathrm{cc})\end{array}$ & $\begin{array}{c}\text { Tapped density } \\
(\mathrm{g} / \mathrm{cc})\end{array}$ & $\begin{array}{c}\text { Hausner's } \\
\text { ratio }\end{array}$ & $\begin{array}{c}\text { Carr's } \\
\text { index }(\%)\end{array}$ & $\begin{array}{c}\text { Particle size } \\
(90 \% \text { particles } \\
\text { less than })(\mu)\end{array}$ \\
\hline DCL11 & 0.614 & 0.720 & 1.19 & 15 & 250 \\
Sorbolac 400 & 0.360 & 0.780 & 2.16 & 54 & 30 \\
Inhalac 230 & 0.640 & 0.760 & 1.19 & 16 & 230 \\
Respitose SV003 & 0.635 & 0.780 & 1.22 & 19 & 100 \\
Lactohale 300 & 0.350 & 0.770 & 2.20 & 55 & 10 \\
Flowlac 100 & 0.600 & 0.730 & 1.21 & 18 & 220 \\
\hline
\end{tabular}


overcome these problem $20 \%$ overages is recommended in dry powder inhaler formulations to deliver $100 \%$ of active ingredient from the dry powder inhaler and to prevent in evitable retentive losses in DPI device. The emitted dose was increased with respect to the overages and results are shown in Figure 1. The emitted dose (delivered dose) was within the ICH limits (80-120\%). The experiments were conducted in triplicate and the observed mean and standard deviation values are shown in Figure 1.

Beclomethasone dipropionate metered dose inhalers were incorporated with extra doses $(10 \%$ and $15 \%)$ to study the effect of extra doses on valve delivery. The observed mean valve delivery rates $(n=3)$ are shown in Figure 2. It was observed that 230 doses are needed to deliver the required 200 metered doses. The additional doses required were found to be $15 \%$ i.e 30 extra doses.

Further, the effect of overages on emitted dose was also studied from those formulations by incorporating overages $(0-20 \% \mathrm{w} / \mathrm{w})$ to the MDI formulation containing $15 \%$ overdose. $20 \%$ overages are needed for $100 \%$ drug delivery and to prevent the inevitable retained loses either from the inhaler device or from the valve. The observed mean emitted doses $(n=3)$ in presence of overages are shown in Figure 3. Thus an additional 35\% of the formu-

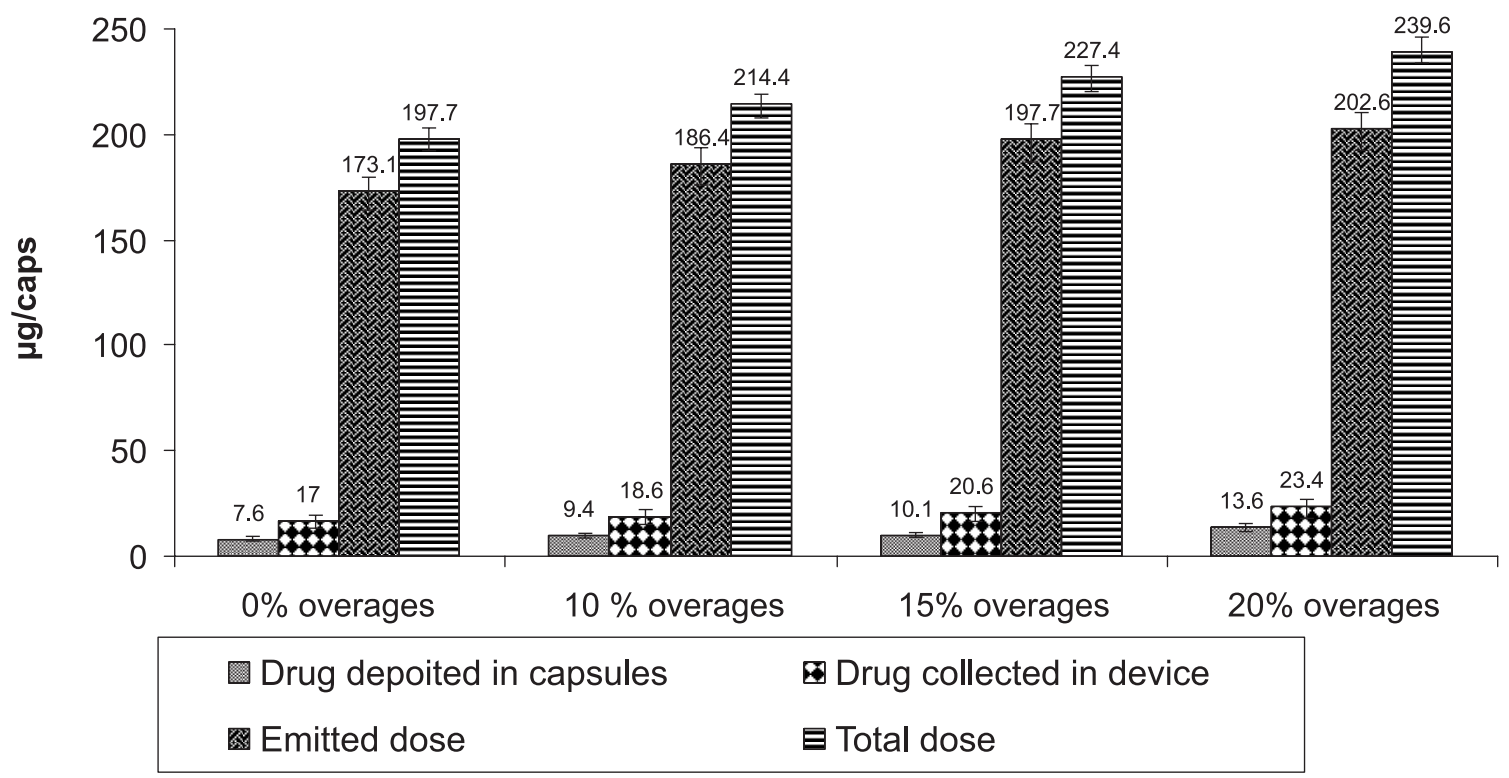

$\overline{\mathrm{X}}$ mean of three values

FIGURE 1 - Histograms correlating emitted dose and overages of beclomethasone dipropionate DPI $200 \mu \mathrm{g}$.

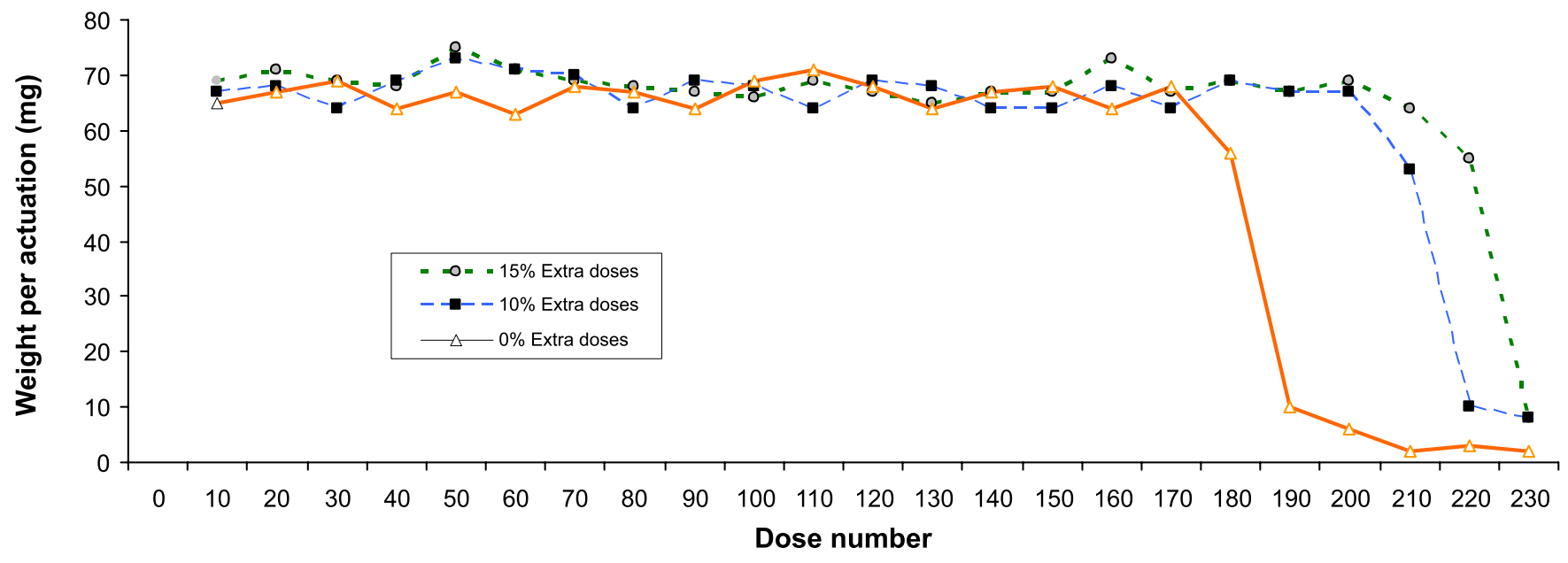

$\bar{X}$ mean of three values

FIGURE 2 - Effect of extra dose on valve delivery from beclomethasone dipropionate MDI containing 200 doses. 


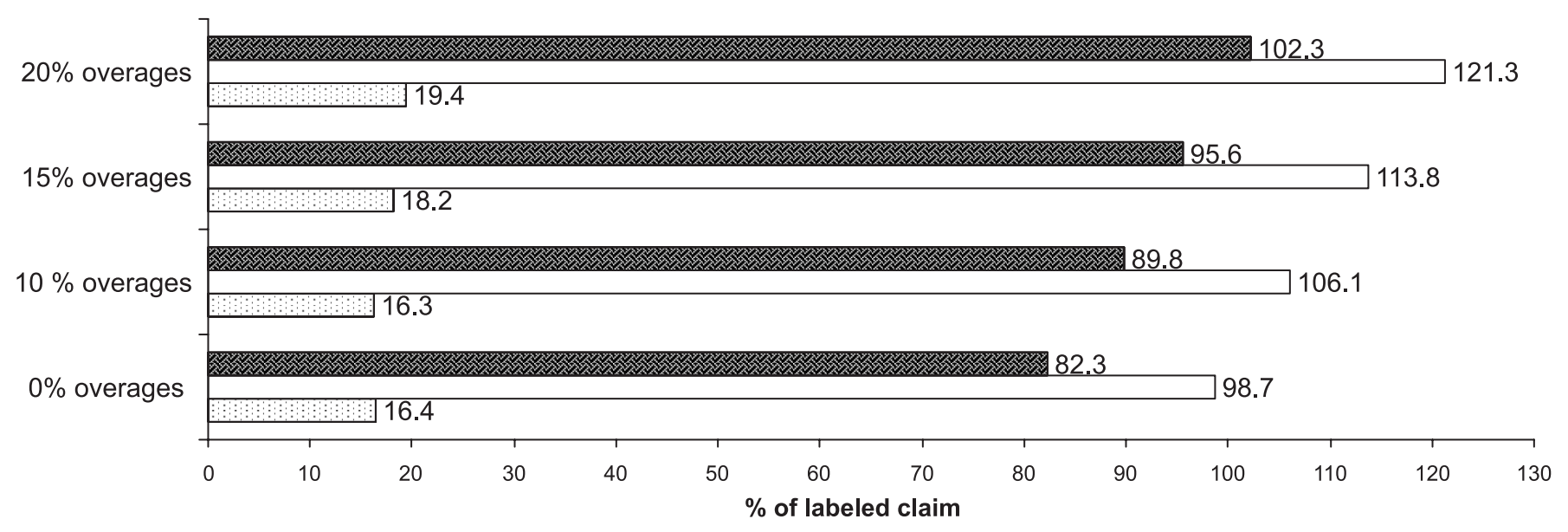

Drug deposited in actuator and can (valve) $\square$ Total dose Emitted dose

$\bar{X}$ mean of three values

FIGURE 3 - Effect of overages on beclomethsaone dipropionate MDI.

lation more than labeled claim is required to deliver the specified doses completely from the MDI device.

Studies were carried out to evaluate the effect of concentration of fine lactose sorbolac S400 (0-30\%) and coarse lactose Inhalac 230 on performance of DPI. All the formulations showed good content uniformity. Aerodynamic particle size is a key parameter for all inhaled products, directly influencing regional deposition in the lungs and respiratory tract. Its measurement is therefore critical during the product development cycle and for quality control. Various sizing techniques are available, but cascade impaction is the method specified for regulatory approval, and hence the most widely used Cascade impactors, including the multi-stage liquid impinger, are by far the most widely encountered means for the in vitro determination of the particle size distribution of aerosols from medical inhalers, both in product development, batch release and in applications with add-on devices. This is because they directly measure aerodynamic size, which is the most relevant parameter to describe particle transport within the respiratory tract. At the same time, it is possible to quantify the mass of active pharmaceutical ingredient in different size ranges independent of other non-physiologically active components of the formulation (Mitchell, 2003). A significant difference was noticed in the emitted dose and fine particle deposition with respect to composition of the formulation. The emitted dose was found to be decreased with increasing concentration of fine lactose and the fine particle deposition was increased with the incorporation of fine lactose (Table II). The mean of three observations along with the standard deviation values are shown in the following table. The low sd values

TABLE II - Characterization of DPI formulation with various portions of fine lactose

\begin{tabular}{|c|c|c|c|c|c|}
\hline \multicolumn{6}{|c|}{ Beclomethasone dipropionate DPI $200 \mu \mathrm{g}$} \\
\hline \multirow{2}{*}{$\begin{array}{l}\% \text { of fine } \\
\text { lactose }\end{array}$} & \multicolumn{5}{|c|}{ Parameters } \\
\hline & $\begin{array}{c}\text { Content uniformity } \\
\text { (\% based on average) }(\bar{x} \pm \text { sd) }\end{array}$ & $\begin{array}{c}\text { Weight variation } \\
(\mathrm{mg})\end{array}$ & $\begin{array}{l}\text { Assay } \\
(\%)\end{array}$ & $\begin{array}{c}\text { Emitted dose } \\
(\%)(\bar{x} \pm \text { sd })\end{array}$ & $\begin{array}{l}\text { Fine particle Dose } \\
\quad(\%)(\bar{x} \pm \text { sd })\end{array}$ \\
\hline 0 & $95.7-115.6$ & $75.3-79.4$ & 121.7 & $101.2 \pm 6.1$ & $7.9 \pm 1.6$ \\
\hline 5 & $91.7-109.3$ & $76.3-79.6$ & 116.6 & $98.6 \pm 5.6$ & $12.5 \pm 0.9$ \\
\hline 10 & $94.6-112.0$ & $72.7-82.4$ & 109.4 & $97.8 \pm 2.9$ & $14.5 \pm 0.8$ \\
\hline 15 & $97.5-106.1$ & $72.4-76.9$ & 109.6. & $91.3 \pm 5.8$ & $15.1 \pm 1.6$ \\
\hline 20 & $97.7-112.3$ & $79.6-82.4$ & 104.4 & $86.4 \pm 6.7$ & $15.0 \pm 1.2$ \\
\hline 30 & $90.3-116.9$ & $71.0-76.4$ & 118.6. & $75.9 \pm 9.4$ & $16.2 \pm 2.0$ \\
\hline
\end{tabular}

$\overline{\overline{\mathrm{x}}}=$ Mean of 3 values; $\pm=$ Indicates the values above or below the mean value 
TABLE III - Physical tests and drug distribution data from beclomethasone dipropionate DPI formulated with different grades of fine lactose

\begin{tabular}{lcc}
\hline & \multicolumn{2}{c}{ Beclomethasone dipropionate } \\
\cline { 2 - 3 } Parameter & \multicolumn{2}{c}{$\boldsymbol{\mu g}$ per Capsules } \\
\cline { 2 - 3 } & Sorbolac 400 & Lactohale 300 \\
\hline Content uniformity (\% based on average) & $84.9-109.4$ & $91.8-109.0$ \\
Weight variation in mg & $72.0-78.7$ & $70.9-79.9$ \\
Assay (\%) & 108.1 & 114.4 \\
Upper Chamber & $183.2 \pm 7.5$ & $135.2 \pm 6.7$ \\
Lower Chamber & $31.2 \pm 2.7$ & $55.8 \pm 3.1$ \\
Capsule & $15.8 \pm 1.6$ & $21.8 \pm 2.1$ \\
Device & $7.6 \pm 1.3$ & $14.2 \pm 1.4$ \\
Total dose & $237.8 \pm 6.2$ & $227.0 \pm 7.1$ \\
Emitted dose & $214.4 \pm 5.8$ & $191.0 \pm 6.4$ \\
\hline
\end{tabular}

in the parameters as emitted dose and fine particle dose indicates that the results are reproducible.

Thus the proportion of fine and coarse lactose influences the performance of dry powder inhalers. Finally it is concluded that $10 \%$ of fine lactose and $90 \%$ coarse lactose is suitable as carrier for development of dry powder inhaler.

Effect of various fine lactose grades (Lactohale 300 and Sorbolac 400) on performance of dry powder formulation was evaluated. All the formulations were tested for weight variation, assay, content uniformity of dose, emitted dose, uniformity of delivered dose; fine particle fraction (Lung deposition) and the mean results along with range/standard deviation values are shown in Table III. All the formulations complied content uniformity of emitted dose and content of active ingredient, however significant difference in fine particle fraction were observed with respect to lactose grades. Lactohale 300 showed better fine particle fraction than Sorbolac 400.

Effect of various coarse lactose grades on performance of dry powder formulation was studied. All the formulations satisfied requirements of the content uniformity of emitted dose and content of active ingredient. The mean fine particle fraction $(n=3)$ observed from DPI formulated with different lactose grades is shown in Figure 4. Respitose SV003 showed better fine particle fraction than other coarse lactose grades (Inhalac230, DCL11 and Flowlac100).

The alcohol may alter the vapor pressure of propellant, solubility of the drug in the propellant and hence spray pattern from the actuator may vary in metered dose inhalation formulation. The effect of alcohol on spray pattern and other parameters was studied and experimental

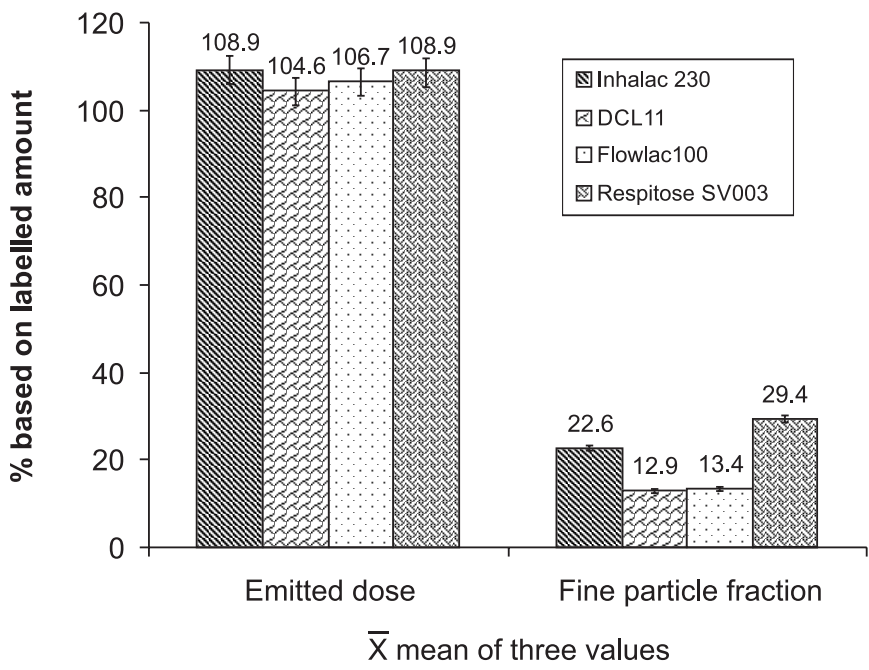

FIGURE 4 - Effect of coarse lactose grade on lactose grade on beclomethasone diprionate DPI performance.

results are shown in Table IV. Lower concentrations of alcohol resulted in low valve delivery and higher concentration exhibited more leak rate. Hence, optimum alcohol concentration $(5-10 \% \mathrm{w} / \mathrm{w})$ is necessary for effective valve delivery and lower leak rate.

The HFA based beclomethasone dipropionate MDIs of $100 \mu \mathrm{g} \& 200 \mu \mathrm{g}$ were evaluated for leak rate, valve delivery, net fill weight and spray pattern. The experimental results indicated the leak rate of $2.1 \pm 0.3 \& 1.8 \pm 0.1 \%$ per year, valve delivery of $63 \pm 4 \& 64 \pm 6 \mathrm{mg}$, net fill weight of $17.0 \pm 0.2 \& 17.2 \pm 0.3 \mathrm{~g}$ and spray pattern of $12.1 \pm 0.2$ $\& 12.5 \pm 0.2 \mathrm{~mm}$.

MDI formulations were evaluated for emitted dose and fine particle fraction with twin impinger apparatus and samples were analyzed with HPLC technique. Emitted 
TABLE IV - Characterization of MDI formulated with various concentrations of alcohol

\begin{tabular}{ccccc}
\hline \% alcohol & Leak rate (\% per year) & Valve delivery $\mathbf{( m g )}$ & Net fill weight $(\mathbf{g})$ & Spray pattern $(\mathbf{m m})$ \\
\hline 0 & $2.1 \pm 0.1$ & $63 \pm 4$ & $17.0 \pm 0.2$ & $12.1 \pm 0.2$ \\
2.5 & $1.8 \pm 0.3$ & $64 \pm 5$ & $17.2 \pm 0.3$ & $12.5 \pm 0.3$ \\
5.0 & $1.9 \pm 0.2$ & $68 \pm 3$ & $17.5 \pm 0.2$ & $13.1 \pm 0.2$ \\
7.5 & $1.5 \pm 0.3$ & $64 \pm 5$ & $17.6 \pm 0.4$ & $13.2 \pm 0.3$ \\
10.0 & $1.9 \pm 0.2$ & $62 \pm 6$ & $17.6 \pm 0.3$ & $14.5 \pm 0.1$ \\
15.0 & $1.9 \pm 0.1$ & $64 \pm 3$ & $17.2 \pm 0.4$ & $14.6 \pm 0.2$ \\
20.0 & $2.1 \pm 0.2$ & $64 \pm 9$ & $17.0 \pm 0.3$ & $15.9 \pm 0.3$ \\
$\mathrm{n}$ & 3 & 10 & 5 & 10 \\
\hline
\end{tabular}

$\mathrm{n}$ : Number of replication

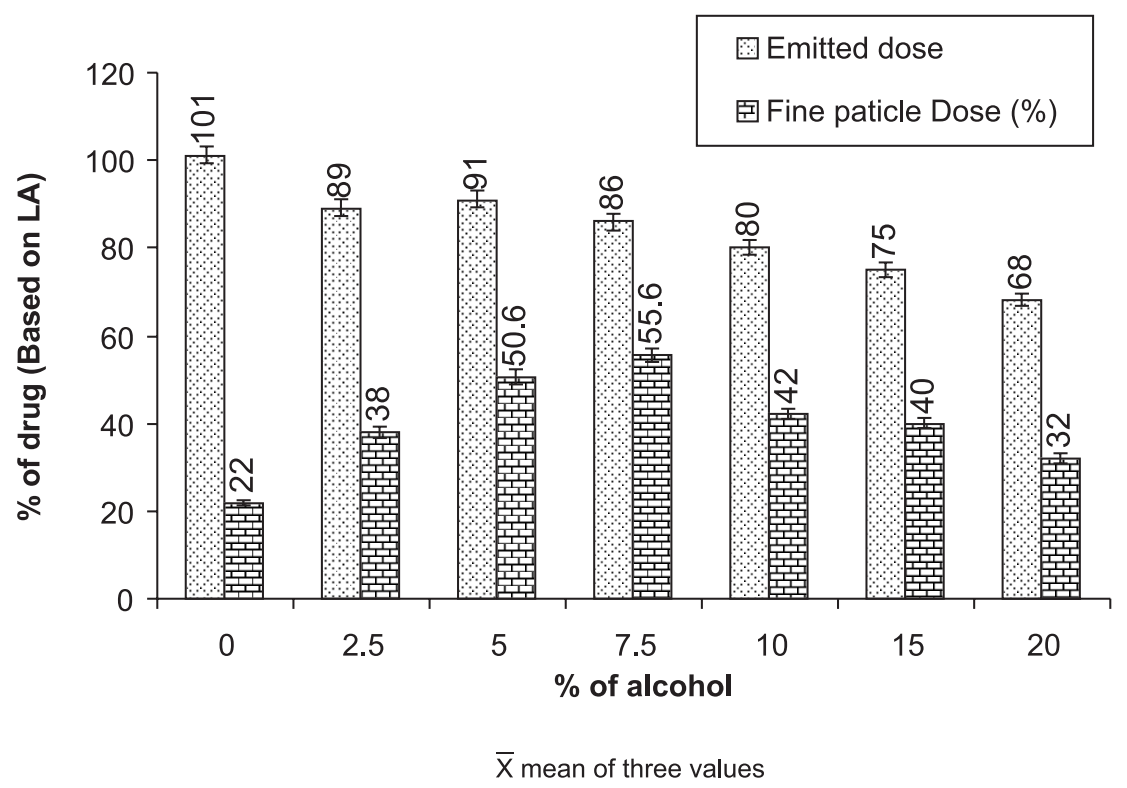

FIGURE 5 - Effect of alcohol content on ED and FP from beclomethasone dipropionate HFA MDI $100 \mu \mathrm{g}$.

dose, fine particle fraction were inversely proportional to alcohol content and indicated that the $5-10 \% \mathrm{w} / \mathrm{w}$ alcohol content is preferred to get optimum emitted dose and fine particle fraction and results were given in Figure 5.

Drug distribution in various stages was observed with 10,15 and 20 capsules of beclomethasone dipropionate DPI in Anderson cascade impactor and beclomethasone dipropionate HFA MDIs containing $0.33 \mathrm{~mm}$ diameter actuator were tested for particle size distribution with Anderson cascade impactor. The observed mean drug distribution pattern in various stages of cascade impactor given is in Table $\mathrm{V}$. The retentive losses were found to be less in sample size 20 capsules.

Fine particle fraction and emitted dose were better with 20 capsules sample size when compared with 10 and 15 samples size (Table VI) and drug distribution pattern was observed. There is no correlation observed in between sample size and Anderson cascade data. Good recovery was observed for beclomethasone dipropionate with sample size 20 .

The stability studies were carried out as per ICH guidelines for HFA based MDI formulations of beclomethasone $200 \mu \mathrm{g}$ and beclomethasone DPI formulations stored at $40{ }^{\circ} \mathrm{C} / 75 \% \mathrm{RH}$ and $25^{\circ} \mathrm{C} / 60 \% \mathrm{RH}$ as per ICH guidelines and results showed that these products are stable at $25{ }^{\circ} \mathrm{C} / 60 \%$ RH (Table VII and Table VIII).

\section{CONCLUSION}

Dry powder inhalers and HFA based metered dose inhalers are developed for beclomethasone dipropionate. The performance of dry powder inhaler is found to be dependent on overages, proportion of fine and coarse lactose and the lactose grade employed in the preparation 
TABLE V - Anderson cascade distribution with various sampling sizes of beclomethasone dipropionate DPI $200 \mu \mathrm{g}$ and beclometasone MDI $200 \mu \mathrm{g}$

\begin{tabular}{lcccc}
\hline \multirow{2}{*}{ Sample size } & \multicolumn{3}{c}{$\boldsymbol{\mu g}$ /capsule (Average of three trials) } & $\begin{array}{c}\text { Beclomethasone } \\
\text { HFA MDI } \\
\mathbf{2 0 0} \boldsymbol{\mu g}\end{array}$ \\
\cline { 2 - 4 } & $\mathbf{1 0}$ capsules & $\mathbf{1 5}$ capsules & $\mathbf{2 0}$ capsules & -- \\
\hline Device & $16.21 \pm 1.5$ & $18.64 \pm 1.1$ & $16.10 \pm 1.5$ & -- \\
Capsules shells & $13.40 \pm 1.3$ & $15.30 \pm 0.9$ & $10.30 \pm 1.4$ & $70 \pm 0.2$ \\
Induction port & $90.00 \pm 6.7$ & $78.00 \pm 8.4$ & $75.00 \pm 8.9$ & -- \\
Pre-separator & $50.00 \pm 4.2$ & $65.00 \pm 6.7$ & $70.00 \pm 8.1$ & $2.4 \pm 0.1$ \\
Stage 0 & $28.71 \pm 1.2$ & $30.10 \pm 2.8$ & $27.60 \pm 3.1$ & $2.2 \pm 0.2$ \\
Stage 1 & $14.84 \pm 2.1$ & $11.56 \pm 1.6$ & $16.89 \pm 2.1$ & $2.0 \pm 0.2$ \\
Stage 2 & $7.44 \pm 0.8$ & $8.15 \pm 1.1$ & $7.69 \pm 2.4$ & $1.2 \pm 0.05$ \\
Stage 3 & $11.81 \pm 1.3$ & $12.56 \pm 1.7$ & $10.96 \pm 1.8$ & $1.6 \pm 0.1$ \\
Stage 4 & $6.13 \pm 0.9$ & $6.18 \pm 0.9$ & $7.21 \pm 1.1$ & $2.2 \pm 0.1$ \\
Stage 5 & $2.34 \pm 0.2$ & $2.34 \pm 0.4$ & $2.84 \pm 0.6$ & $33.0 \pm 0.4$ \\
Stage 6 & $0.39 \pm 0.05$ & $0.32 \pm 0.08$ & $0.34 \pm 0.05$ & $32.4 \pm 0.1$ \\
Stage 7 & $1.85 \pm 0.04$ & $1.53 \pm 0.12$ & $1.65 \pm 0.2$ & $29.0 \pm 0.5$ \\
Filler & $0.00 \pm 0$ & $0.08 \pm 0.02$ & $0.01 \pm 0.0$ & -- \\
\hline Capsules shells + device & $29.61 \pm 2.4$ & $33.94 \pm 3.6$ & $26.40 \pm 2.8$ & \\
\hline
\end{tabular}

TABLE VI - Effect of sample size on cascade impactor testing of beclometasone DPI

\section{Product}

Sample size (capsules)

$\%$ FPF

$\%$ of Emitted dose

$\%$ of Total Dose

MMAD

GSD

\% Based on the Label Amount (LA)

\section{Beclomethasone DPI $200 \mu \mathrm{g}$}

10

$14.98 \pm 1.2$
$106.76 \pm 6.4$
$121.56 \pm 5.9$
$7.87 \pm 0.2$
$3.31 \pm 0.2$

$15.58 \pm 2.1$

$107.91 \pm 5.8$

$124.88 \pm 5.6$

$7.45 \pm 0.3$

$2.65 \pm 0.1$
20

$15.35 \pm 1.5$

$110.10 \pm 5.2$

$123.30 \pm 6.2$

$6.46 \pm 0.2$

$2.34 \pm 0.1$

TABLE VII - Stability data of Beclomethasone DPI $200 \mu \mathrm{g}$ stored at $40 \pm 2{ }^{\circ} \mathrm{C} / 75 \pm 5 \% \mathrm{RH} \& 25 \pm 2{ }^{\circ} \mathrm{C} / 60 \pm 5 \% \mathrm{RH}$

\begin{tabular}{|c|c|c|c|c|c|c|}
\hline \multicolumn{7}{|c|}{ Storage condition : $40 \pm 2{ }^{\circ} \mathrm{C} / 75 \pm 5 \% \mathrm{RH}$} \\
\hline \multirow{2}{*}{ \# } & \multirow{2}{*}{ Characteristics tested } & \multicolumn{5}{|c|}{ Results at testing intervals } \\
\hline & & Initial & 1 month & 2 months & 3 months & 6 months \\
\hline 1 & Description & Complies & Complies & Complies & Complies & Complies \\
\hline 2 & Assay $(\%)$ & 114.3 & 112.2 & 108.5 & 111.2 & 114.8 \\
\hline 3 & Deposition of emitted dose (\%) & 15.7 & 16.2 & 17.8 & 16.9 & 15.5 \\
\hline \multicolumn{7}{|c|}{ Storage condition : $25 \pm 2{ }^{\circ} \mathrm{C} / 60 \pm 5 \% \mathrm{RH}$} \\
\hline \multirow{2}{*}{ \# } & \multirow{2}{*}{ Characteristics tested } & \multicolumn{5}{|c|}{ Results at testing intervals } \\
\hline & & Initial & 3 months & 6 months & 9 months & 12 months \\
\hline 1 & Description & Complies & Complies & Complies & Complies & Complies \\
\hline 2 & Assay (\%) & 114.3 & 112.9 & 114.0 & 113.0 & 113.9 \\
\hline 4 & Deposition of emitted dose (\%) & 15.7 & 16.1 & 15.8 & 15.3 & 15.9 \\
\hline
\end{tabular}


TABLE VIII - Stability data of Beclomethasone HFA based MDI $200 \mu \mathrm{g}$ stored at $40 \pm 2{ }^{\circ} \mathrm{C} / 75 \pm 5 \% \mathrm{RH} \& 25 \pm 2{ }^{\circ} \mathrm{C} / 60 \pm 5 \% \mathrm{RH}$

\begin{tabular}{|c|c|c|c|c|c|c|}
\hline \multicolumn{7}{|c|}{ Storage condition : $40 \pm 2^{\circ} \mathrm{C} / 75 \pm 5 \% \mathrm{RH}$} \\
\hline \multirow{2}{*}{ \# } & \multirow{2}{*}{ Characteristics tested } & \multicolumn{5}{|c|}{ Results at testing intervals } \\
\hline & & Initial & 1 months & 2 months & 3 months & 6 months \\
\hline 1 & Description & Complies & Complies & Complies & Complies & Complies \\
\hline 2 & Assay (\%) & 116.3 & 115.2 & 108.5 & 111.2 & 114.8 \\
\hline 3 & No. of doses & 229 & 226 & 234 & 227 & 224 \\
\hline 4 & Deposition of emitted dose (\%) & 38.8 & 39.9 & 48.6 & 44.6 & 42.7 \\
\hline 5 & Net fill weight $(\mathrm{g})$ & 37.6 & 37.2 & 36.0 & 35.2 & 35.4 \\
\hline \multicolumn{7}{|c|}{ Storage condition : $25 \pm 2{ }^{\circ} \mathrm{C} / 60 \pm 5 \% \mathrm{RH}$} \\
\hline \multirow{2}{*}{ \# } & \multirow{2}{*}{ Characteristics tested } & \multicolumn{5}{|c|}{ Results at testing intervals } \\
\hline & & Initial & 3 months & 6 months & 9 months & 12 months \\
\hline 1 & Description & Complies & Complies & Complies & Complies & Complies \\
\hline 2 & Assay (\%) & 116.3 & 114.9 & 116.0 & 113.0 & 113.9 \\
\hline 3 & No. of doses & 229 & 232 & 225 & 232 & 230 \\
\hline 4 & Deposition of emitted dose (\%) & 38.8 & 40.1 & 38.9 & 42.0 & 39.1 \\
\hline 5 & Net fill weight (g) & 37.0 & 37.2 & 37.0 & 36.2 & 36.4 \\
\hline
\end{tabular}

of dry powder inhalers. The performance of dry powder inhalers containing beclomethasone dipropionate was found to be optimum when the DPI is formulated with 10:90 ratio of fine lactose (Lactohale 300):coarse lactose (Respitose SV003) and having 20\% w/w overages. In pressurized metered dose inhalation formulation, overages are required to reach the $100 \%$ of target amount drug to the patient. An extra $20 \%$ is recommended in the formulation. All the developed metered dose inhalers met the pharmacopoeial requirements. The formulations are stable at recommended storage conditions i.e. $25^{\circ} \mathrm{C} / 60 \%$ $\mathrm{RH}$. This investigation successfully yielded an alternative CFC metered dose inhaler for effective delivery of beclomethasone dipropionate.

\section{ACKNOWLEDGEMENTS}

The authors are thankful to the Management of Bapatla College of Pharmacy and NATCO Pharma Limited, Kothur for providing appropriate facilities.

\section{REFERENCES}

BISGARD, H.; CALLAGHAN, C. O.; SMALDONE, G.C. Drug delivery to the lung. New York: Marcel Dekker Inc, 2002. p.1-20, p.105-142, p.337-364, p.371-387.
GUIDANCE FOR INDUSTRY. Metered Dose Inhaler (MDI) and Dry Powder Inhaler (DPI) Drug Products. Chemistry, Manufacturing, and Controls Documentation. Rockville: Food and Drug Administration, 1998. 62 p. (Draft Guidance).

FLAMENT, M.P.; LETERME, P.; GAYOT A. The influence of carrier roughness on adhesion, content uniformity and the in vitro deposition of terbutaline sulphate from dry powder inhalers. Int. J. Pharm, v.275, p.201-209, 2004.

HARTWIG, S.; BERND, W. M. Metered-dose inhaler formulations with beclomethasone-17, 21-dipropionate using the ozone friendly propellant R 134a. Eur. J. Pharm. Biopharm., v.46, p.77-83, 1998.

INDIAN PHARMACOPOEIA. Ghaziabad: The Indian Pharmacopoeia Commission, 2007. v.2, p.638-652.

KEITH, J. M.; GARY, P.M. Transition to CFC-free metered dose inhalers into the new millennium. Int. J. Pharm, v.201, p.89-107, 2000.

MERCK INDEX. An encyclopedia of chemicals, drugs and biological. 13.ed. New York: John Wiley and Sons, 2001. p.1367. 
MICHAEL, L.; RICHARD, K. P.; SUSAN, J. G.; ERIC, D. O. B.; HEATHER, A. B. Metered-dose inhalers I: drug content and particle size distribution of beclomethasone dipropionate. J. Pharm. Biomed. Anal., v.14, p.793-800, 1996.

JOLYON, P.; MITCHELL AND MARK W. NAGEL. Cascade impactors for the size characterization of aerosols from medical inhalers: their uses and limitations. J. Aerosol Med., v.16, p.341-377, 2003.

SAINT-LORANT, G.; LETERME, P.; GAYOT, A.; FLAMENT, M.P. Influence of carrier on the performance of dry powder inhalers. Int. J. Pharm., v.334, p.85-91, 2007.

STEIN, S.W. Size distribution measurements of metered dose inhalers using Andersen mark II cascade impactors. Int. J. Pharm., v.186, p.43-52, 1999.
SWEETMAN, S.C. Martindale. The complete drug reference. 36.ed. London: Pharmaceutical Press, 2009. p.1516-1518.

MONTREAL Protocol on substances that deplete the ozone layer. 1994 Report of the methyl bromide technical options committee. Nairobi: UNEP, 1994. p. 56276-56298.

WILLIAMS, R.O; TAFT, D.R.; MCCONVILLE, J.T. Advanced drug formulation design to optimize therapeutic outcomes. New York: CBS Publishers, 2008. p.1-50.

Received for publication on $10^{\text {th }}$ January 2011 Accepted for publication on $22^{\text {th }}$ May 2013 